\title{
Autonomous Decentralized Enterprise Model -A New Wave in Web 2.0 Type E-commerce ${ }^{1}$
}

\author{
Feng Liu ${ }^{1}$ and Makoto Hirano ${ }^{2}$ \\ ${ }^{1}$ Southwest Jiaotong University, China \\ ${ }^{2}$ Kochi University of Technology, Japan
}

\section{Introduction}

At the beginning of the twenty-first century, business conducted over the Internet (referred here as 'e-commerce'), with its dynamism, rapid growth, and high competitiveness, promises new avenues for the creation of wealth (Amit, Zott, 2001). Established firms are creating new online businesses, while new ventures are exploiting the opportunities the Internet provides. Moreover, since the emergence of Web 2.0 in 2004, users can do more than just retrieve information. The role of common customer in business has changed to a great extent, the customers have become more influential on sales and on new item development through their Internet activities (weblogs, forums, personal web pages, wikis, podcasts, social bookmarks, RSS feeds and other forms of many-to-many publishing). To some extent, Web 2.0 facilitates the construction of autonomous decentralized network outside the enterprises. This network, composed of autonomous customers and suppliers, and has become a topic, which caused extensive attention in the theoretical research and business practice.

Accompanying the environmental shift outside the E-enterprises, inside the business organization, traditional pyramid-style management models, such as the functional structure, multi-divisional structure or matrix organizational form, no longer suit the new external environment. In this chapter, a new wave of organization model inside enterprises the Autonomous Decentralized Enterprise Model (ADEM) will be described, and its process and formulation mechanism will be analyzed.

The chapter will be organized as follows:

First, the paradigm shift in the external business environment, which urges the transformation of the enterprise organization, will be introduced as background; then, the Autonomous Decentralized System (ADS), as the theoretical origin of ADEM, and its development will be presented as a revolutionary viewpoint in interdisciplinary fields. The practical application in real-time production system and theoretical innovation in business and management field based on the ADS will also be reviewed. The main part of the chapter

${ }^{1}$ Portions of this article have been previously presented in IEMC Europe 2008 and published in the proceeding of it. 
will describe the mechanism and organizational characteristics of ADEM, which describes an inter-organization of enterprises through broad collaboration and interdependence between agents. All agents in a mutually dependent relationship can benefit from increased adaptability over their environment. Finally, the case study of a Japanese E-commerce enterprise will be examined to afford detailed cognition about ADEM. Yumenomachi Souzou Iinkai (Japanese for "dream creation committee") is a burgeoning Internet portal enterprise in Japan; most of its current staffs aim to become independent and start their own Internet business companies in the future. The CEO, Ms. Nakamura, has been encouraging their ambitions, thinking that that will lead to her company's emergence as a virtual cluster of new Internet businesses owned by her current employees. This new organization model is still at an early stage of ADEM, but it already demonstrates the rudiments of an autonomous decentralized inter-organization system.

\section{The paradigm shift on the E-business Model in Web 2.0 era}

\subsection{E-commerce and e-commerce enterprises}

The emergence of E-commerce has created a novel marketplace. However, There are various ways to definite what constitutes e-commerce. Bakos (1997) argued that it is the electronic market systems that create a space where buyers and sellers converge. Zwass (1996) proposed an architecture that embraces the aforementioned perspectives as two components of an e-commerce structure. Chang, Jackson (2002) argued that e-commerce includes not only buying and selling goods, but also various processes within and across organizations. E-commerce can also be loosely defined as a business process that uses the Internet or other electronic medium as a channel to complete business transactions. As classified by Geoffrion and Krishnan (2001), e-commerce consists of three areas: (1) consumer-oriented activity and (2) business-oriented activity supported by (3) the e-commerce technology infrastructure. The consumer-oriented activities consist of business-to-consumer (B2C), consumer-toconsumer (C2C), and government-to-consumer (G2C) activities. The business-oriented activities comprise business-to-business (B2B), business-to-government (B2G), and government-to-business (G2B) activities. The technology infrastructure relates to network infrastructure, network applications, decision technologies, and software tools and applications. In the terms of E- commerce firms, Amit and Zott defined an e-commerce firm as one that derives a significant proportion (at least 10\%) of its revenues from transactions conducted over the Internet. This definition of an e-commerce firm is quite broad. It includes, for example, Internet Service Providers, and companies that have not aligned all of their internal business processes with the Internet but that use the Internet solely as a sales channel. On the other hand, it excludes providers of Internet related hardware or software, that is, firms that facilitate e-commerce but that do not engage in the activity themselves (e.g., a backbone switch manufacturer, such as Cisco Systems). The companies that derive all of their revenues from e-commerce (so-called "pure plays") are relatively easy to identify using publicly available descriptions of their major lines of business (e.g., Amazon.com).

Within this broad definition of e-commerce activities, we are inclined to the definition that e-commerce as the use of computing and communication technologies to engage in a wide range of activities up and down the value-added chain, both within and outside the organization (Chang, 2002). And we will restrict our attention mainly to consumer-oriented and business-oriented activities, as well as decision technologies, strategy management that 
are employed for intra-organization of EC. The business activity of Yumenomachi B2B2C (business-to-business-to-consumer), which is originated from B2C, is defined as e-commerce model in which a business provides some product or service to a client business that maintains its own customers.

\subsection{Web 2.0 and e-commerce business model}

In recent years, the emergence of the phrase Web 2.0 is a trend in web design development and can refer to a perceived second generation of web-based communities and hosted services - such as social-networking sites, wikis, and folksonomies - which aim to facilitate creativity, collaboration, and sharing between users. Many of the technology components of "Web 2.0" have existed since the early days of the Web. However, the concept of Web 2.0 was explicitly formulated in the first O'Reilly Media Web 2.0 Conference in 2004. As Bart Decrem, founder and former CEO of Flock, declared, the most outstanding characteristic of Web 2.0 is "participatory Web". This new environment certainly will affect the marketing strategy and organization management of the entities in the value chain, especially for the 'pure plays' of EC.

Don Tapscott and Anthony D. Williams argued (2006) that the foundation of Web 2.0 economy is mass collaboration. They claimed that the new media companies should utilize well this feature of Web 2.0 to make profit. According to Tapscott and Williams, openness, sharing, peering, and global thinking would be crucial aspects of the success of this new "Wikinomic", or collaborative Internet economy. Tapscott and Williams also classify the Web 2.0 business models in seven categories, suggesting that using these models could help a company to successfully enter in the modern Internet business by using the new wave of software applications. In this era, the line between creators and consumers has become vaguer than ever before, and in some cases most of the creative work and content creation is done by the users (Youtube.com, Slashdot.com or Wikipedia.org). Tapscott and Williams (2007) finally propose "models where consumers, employees, suppliers, business partners, and even competitors co-create value in the absence of direct managerial control".

In the Web 2.0 era, users can do more than just retrieve information. They can build on the interactive facilities of "Web 1.0" to provide "Network as platform". Users can own the data on a Web 2.0 site and exercise control over that data. These sites may have an "Architecture of participation" that encourages users to add value to the application as they use it. As an IBM social networking analyst, Dario de Judicibus, has proposed, Web 2.0 focused more on social interactions and architectural implementation: "Web 2.0 is a knowledge-oriented environment where human interactions generate contents that are published, managed and used through network applications in a service-oriented architecture."

According to NEC (Nippon Electric Company), the substantial change to the enterprise management and business strategy caused by Web2.0 could be summarized as three points:

(1) The marketing has changed. Before purchase, the potential customers always retrieve information from the user side and compare with other commodities in internet. In addition, after purchase, they also send their impression and evalutaion to the interent. Therefore, consumers have become more influential on sales or new items development by enterprises through their Internet activities in the Web 2.0 era. Thus, an interactive participation marketing operation corresponding to such Web2.0 purchase action is requested for the enterprises. 
(2) The manner of communication in/out enterprises has changed. Out the enterprise, a large amount of information, which is sent and exchanged by blogs, SNS and so on, formed the so called "collective intelligence". This kind of participative wisdom will produce new and useful information in succession. If a similar phenomenon could happen inside the enterprise, the emloyees' capability for receiving and sending information would be upgraded. Therefore, an enviroment of active communication will cause a revolution of the enterprise culture.

(3) The means of the enterprise information system have changed. In Web2.0, accompanying the advancement of the web technology, more and more enterprises disclose and provide their own services and information by network. Whereby, it becomes more possible to construct the information system at low cost in short term by combining the external service and information.

In contrast to the old traditional websites system, in some extent, Web 2.0 facilitates the construction of the autonomous decentralized network "outside" enterprises. This network is constituted by each autonomous customers and supplier.

E-commerce, which entered to the EC2.0 era correspondingly, has attracted tremendous attention of scholars in the fields of how to manage the new customers relationship, how to integrate the intelligence of the customers, which is the resource of the network outside the enterprises. However, in terms of the inter-organization of the e-commerce in Web 2.0 era, yet, the research is currently comparatively sparse. The literature to date has neither articulated the central issues related to this new phenomenon, nor has it developed a theory that captures the unique features of the virtual organization in this market. This chapter attempts to initiate some research prospective by seeking to identify some characteristics of inter-organization in e-commerce in the new era.

\section{Autonomous Decentralized System (ADS)}

\subsection{What is ADS?}

Worldwide, markets and technologies have been rapidly changing and advancing. The users requirements have been diversified and grown unpredictable. The service time of the application systems are required to be longer and longer. The cost reduction of the computing networks resources has required for the easy-to-use, easy-to-construct and easy-to-modify. As the computing resources become less restrictive, the on-line property consisting of on-line expansion, fault-tolerance and on-line maintenance is required more (Mori, 1984). However, the conventional technologies have been developed under the extension of the centralized system concept based on the standpoint that the totality has to be previously defined. This standpoint is inconsistent with the new requirements of the system. Under these evolving situations, as the breakthrough over the conventional system, Autonomous Decentralized System (ADS) has been proposed in 1977 for resolving the on-line property to achieve the step-by-step expansion, maintenance / test and fault-propagation prevention without stopping the total system. The research and development has been accelerated in the world not only for the control systems but also for the wide-area information systems (Mori, 2004). The technologies have been developed in the diverse fields of transportation, factory automation, utility management, satellite on-board control, newspaper printing factory, information services, e-commerce, community service, and so on. 
The ADS concept was derived from an analogy to living organisms. Every living thing is composed by cells and performs effectively by virtue of the biological operations of the functional organisms. Each cell is totally self sufficient for the information for its living and multiplication. None of these cells is involved in any master-slave relationship. They are completely autonomous in their survival and function. In the body, all the organisms are performing their own function in unit with other organs. Compared to the homogenous functions of cell, the functions of the organs can be characterized to be heterogeneous. Their basic autonomy is not violated by any communication between cells and organs. Therefore, the living body could perform its function of living and growing through its cellular structure while ensuring assurance, agility, mobility and autonomy. In conclusion, according to Mori (Mori, 1984) the system as a biological organism has the following attributes:

(1) The system always has faulty parts.

(2) It changes constantly, alternating between operation, maintenance, and growth.

(3) It keeps accomplishing its objective and function almost completely.

That is, the system is defined under these two standpoints:

(1) Being faulty is normal;

(2) The system is a result of the integration of subsystems.

In other words, the decentralized system integrates several subsystems and has a composite life cycle. The independent subsystems of the decentralized system consist of uniform components, which are capable of interacting with each other to perform global functions. However, nothing monitors or controls these subsystems in an integrated manner. The monitoring system is only a subsystem and, like an organ in a living organism, there is no hierarchy of subsystems. Moreover, a whole system cannot be previously defined. The system is the integration of the current subsystems, some of which may be faulty, undergo modification and repair. On this standpoint, ADS should satisfy the following two properties.

(1) Autonomous controllability: If any subsystem fails, is repaired and/or is newly added, the other subsystems could continue to manage themselves and to perform their own responsible function.

(2) Autonomous coordinability : If any subsystem fails, is repaired and/or newly added, the other subsystems can coordinate their individual objectives among themselves and it can operate in a coordinated fashion.

These two properties assure on-line expansion, fault tolerance and on-line maintenance of the system. Every subsystem is required an intelligence to manage itself, without directing to and being directed from the other subsystems and to coordinate with the other subsystems.

If ADS is employed in a homogeneous system, the system has the following representative characteristics:

(1) Fault tolerance: The partial failure of the system does not hinder the system operation in any way. The normal designed operation of the system can performed without propagating the fault to the rest of the system.

(2) On-line expansion: The system operation is not affected in any way when additional subsystem are added or deleted.

(3) On-line maintenance and testing: Routine maintenance and testing operations can be carried out on the system without stopping system operation. 
If ADS is employed in a heterogeneous system, the properties, which the ADS should satisfy, are exhibited as follow:

(1) System agility: The environment should match the dynamics of the system flexibility.

(2) Mobility: The functional behavior of each subsystem should incorporate mobility so it can migrate to other systems.

(3) Assurance: The system should be able to collaborate with other systems in case it is unable to perform its function alone under evolving conditions (Ahmed, 2004).

The subsystems, in order to realize an autonomous decentralized system with autonomous controllability and autonomous coordinability, are required to satisfy the following three conditions:

(1) Equality: Each subsystem must be equal. That means every subsystem can manage itself without being directed or giving direction to others.

(2) Locality: Each subsystem manages itself and coordinates with others only based on local information.

(3) Self-containment: Each subsystem is self-contained in functions to manage itself and coordinate with others.

\subsection{The application of ADS and trends}

The ADS has been applied to a number of applications that involve the production system, management of information and control function in an adaptive information service system. The concept has been successfully applied in traffic control and information systems, for example, the ATOS (Autonomous Train Operation System), which is deployed in Tokyo metropolitan train traffic control system. Telecommunications-based information services, which are envisaged to expand in the future giving rise to more intelligent networks, are another beneficiary of ADS technology. A typical application of the ADS concept applied to production systems has been in the newspaper production. ADS allows immediate changes in format and volume according to the article contents, as well as coordinated production between locally distribute printing plants. The architecture allows flexible change of the production schedule while ensuring reliability. The technical concepts of ADS are also applied in highly reliable steel manufacturing system. Distributed systems that include many autonomous entities can benefit from the ADS technology.

The future of ADS is seen to be associated with the autonomous community concept where each component of the community will be autonomously handled. ADS has been instrumental in boosting productivity and lowering costs in manufacturing systems and has been approved as the de-facto standard in factory automation.

\section{The ADEM}

\subsection{The proposal of ADEM}

The concept of ADS is adopted in the field of the inter-organization of enterprises through broad collaboration and interdependence between each element. Interdependence refers to mutual dependency between units within an organization. Both units in a mutually dependent relationship can benefit from increased power over their environment. Following the traditional classification of Thompson (1967), there are three grades of interdependence. In the "pooled dependency", the most basic form of interdependence, only the resources are 
shared, there is no real interaction between the different groups. In the "sequential dependency", the output of a group becomes the input of another. And, finally, in the "reciprocal dependency" each group receives and produces work from and for several other groups in an interactive manner, forming a complex network.

Organizations can improve their performance by increasing dependency of organizational units. Lee, Pak observed the inter-firm collaboration in B2B electronic commerce. Based on the survey conducted in the grocery industry, they pointed out that the real source of performance improvement in B2B EC is the collaboration enabled by the electronic network. Next, the applicability of the ADEM in Web 2.0 era will be analyzed. At present, the autonomous decentralized model is just a new emerging organization model phenomenon in Japanese E-commerce enterprises. Maybe its applicability and viability in the future will be doubted as any other fangle. This chapter just initiated a tentative analysis, which will be focused on two dimensions as follow: external environment and internal factor.

In the viewpoint of external environment, the prevalent application of Web 2.0 offers chance as well as requirement to new organization models. On one hand, the competition was enhanced broadly. During the past 15 years, we have witnessed the proliferation of Internet firms and the subsequent large-scale collapse of the Internet sector, which triggered an economic recession. According to Webmergers.com (2002), more than 800 Internet firms have gone out of business since January 2000. Those that remained had to adapt to the marketplace by changing their organizational strategies to survive. The sustainable development becomes an urgent topic in the field of EC. An effective and applicable organizational model is under expectation. More extensive collaboration and interdependence seems to be viable approach to exploit the development space. On the other hand, Web 2.0 also affords the unprecedented opportunity for enterprises to integrate the intelligence of all entities involved in the supply chain and value chain, including the suppliers, partners, customers and even competitors. For example, ERP (enterprise resource plan), CRM (customers relationship management), EDI (electronic data interchange), SCM (supply chain management), advanced planning and optimization solutions (APS) have been already realized and executed by many enterprises to maximize their profit and promote their efficiency in the Web 2.0 market. Also, the entry barrier is decreased, allowing more entrepreneurs to participate in the business. More participators make it more favorable to establishment and realization of collaboration network.

In the viewpoint of the internal factors, for a lot of individuals with their own small-scale start-ups, they are seeking for the external technological, financial, customer resource sharing cooperation actively. They want to realize their dream to play a role in some field, keep their own independence, not just simply merge or be acquired. The employees in the enterprises also seek for opportunities to create their own business inside the enterprises. They need the technology or marketing platform of the enterprises. Therefore, the management system faces to expansion or reduction any time as same as the computing system.

Combining both the external and internal factors, the predicted wave may still be doubted. Nevertheless, there is no doubt that the rapid growth and adoption of the collaboration and connection between EC enterprises has already had great impact on all the aspects of their business, including customer acquisitions, marketing, human resource management, finance, information systems and operations. 


\subsection{Case study}

The detailed data was gathered on the case study company mainly from field survey, formal/informal interview and publicly available sources: IPO prospectuses, annual reports, reports from investment analysts, and the web site of the company.

\subsubsection{Basic data of Yumenomachi Souzou linkai Co.,Ltd}

Yumenomachi, which translates as Dream Street Creation Committee, aims to create exceptional services to assist people to live more conveniently and comfortably. Yumenomachi was established in 1999 in Osaka. Currently it has 40 employees. The main business includes:

1) Food delivery service website "Demae-kan"

2) Home maintenance service website "Kaketsuke-kan"

3) Take-out food and dinner reservation service website "Yoyaku-kan"

Yumenomachi began to gain profit from August 2005, fives years after its delivery service launched. In 2006, it became IPO Company. Figure 1 shows the revenue and profit shift of Yumenomachi after its launch.

\section{口Revenue DProfit}

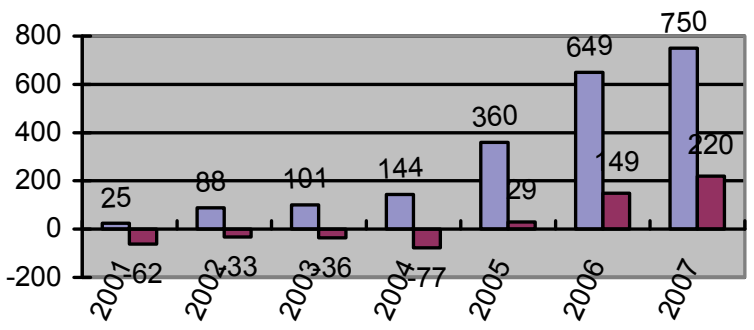

Fig. 1. Profit and revenue from 2001-2007 of Yumenomachi Unit: Million Yen http://www.yumenomachi.co.jp/news_release/press/071015_3.pdf

Demae-kan is the first and also main business of Yumenomachi. In Japan, the food service industry has undergone a decreasing tendency for these ten years after its peak in 1997, but the market scale of takeout and delivery food has enlarged steadily along with a decrease of the size of households and the change of lifestyle in Japan. According to the statistics, the delivery food market reaches around 1600 billion Japanese yen per year. Demae-kan website was originated from the idea to afford order service in Internet conveniently and quickly. Figure 2 shows the B2B2C business model of Demae-kan. 
1: publish the menu and ads



2: order 3: order information

4: confirm order 5: payment

6: charge and month fee

Fig. 2. Business flow chart of Demae-kan

http://www.yumenomachi.co.jp/ir_information/

Customers can order food, such as Pizza, Sushi, Chinese food or others through Demae-kan for free; Demae-kan will send the order message to the appointed restaurants by fax. After the confirmation of the menu and cooking time from restaurant, Demae-kan will send it back to customers to reconfirm. Then the restaurant will send the food to the customers and get the paid directly from them. Demae-kan obtains revenues through a member fee of the restaurants (monthly advertisement publishing fee 3,000 yen) and a 5\% commission on each order.

Till November 2007, there are already 7613 restaurants joined in Demae-kan, and around 300,000 orders per month. In Kansai and the Tokyo metropolitan area, the number of the restaurants increases by around 130 stores every month.

One of the outstanding features of the Demae-kan is to concentrate on not only the chain stores but also the community-based stores like local noodle restaurants. However, the chains stores have its advantage to the business of Demae-kan, the treatments are the same as local small stores according to the principle of CEO, Ms. Nakamura, because one of her wish is to assist the local development and prosperity.

As the sister website of Demae-kan, Kaketsuke-kan started in September, 2005. Its business focuses on homemaking service. The customers can order through Internet for gas changing, key changing, tap fix, pest killing and other related services. This website is constructed based on the service of major consignment company Japan Best Rescue System Company.

The third business, Yoyaku-kan, launched in June, 2007. The customers can make reservation before they go to the restaurant or take-out food with the service in Yoyaku-kan.

\subsubsection{Organization strategy}

The B2B2C business model and its forerunner position are the advantageous of Yumenomachi. Moreover, its unique organizational strategy seems to be the requisite of the sustainable development of the company.

1) Independence of the employees 
As a high-speed developing EC company, most of the staffs are young people; the average age of the staff is around 32 years old. The promotion and salary are only decided by the achievement of the staff, no relationship with the diploma or working time.

The manager pays attention to the independence of each staff. She always encourages them and also promises to support them to initiate their own business. During the process of recruitment, the company prefers the applicants who have the intention to start their own business. The personnel can learn the business knowledge and strategy working in this company. The manager expects that the employees can be independent in their own field of business and then collaborate together to form a bigger network. $60 \%$ of the male staff has their own entrepreneur ideas. One of the staff wants to open a sports equipment delivery website in the future.

2) Collaboration inter-enterprises and intra-enterprises

Since its establishment, Yumenomachi has constructed its collaboration network with several major companies. Its process of development is also a process to enlarge the cooperation with its partners. The Table 1 shows the detail of the cooperation relationship of Yumenomachi.

\begin{tabular}{|c|c|c|}
\hline Date & Partner & Established Service \\
\hline July, 2004 & $\begin{array}{l}\text { Index Company } \\
\text { http://www.index-hd.com/ }\end{array}$ & Mobile delivery service \\
\hline August, 2004 & Yahoo & $\begin{array}{l}\text { July 2005, Portal site } \\
\text { "Yahoo Delivery Service" }\end{array}$ \\
\hline June, 2005 & $\begin{array}{l}\text { Japan Best Rescue System Company } \\
\text { http://www.jbr.co.jp/ }\end{array}$ & Kaketsuke-kan \\
\hline August, 2005 & AU official website & Mobile delivery service \\
\hline August, 2006 & $\begin{array}{l}\text { Net Café (Hot-Station Company } \\
\text { http://www.hot-station.co.jp/) }\end{array}$ & \\
\hline August, 2006 & $\begin{array}{l}\text { Mediaflag Company } \\
\text { http://www.mediaflag.co.jp/ }\end{array}$ & $\begin{array}{l}\text { Capital and business } \\
\text { cooperation }\end{array}$ \\
\hline October, 2006 & $\begin{array}{l}\text { Mitsui Sumitomo Card Company and } \\
\text { GMO Payment Gateway Company }\end{array}$ & $\begin{array}{l}\text { Credit service began in } \\
\text { "Demae-kan" }\end{array}$ \\
\hline October, 2006 & "Hot pepper" of Recruitment Company & $\begin{array}{l}\text { "Hot pepper" delivery } \\
\text { service }\end{array}$ \\
\hline April, 2007 & $\begin{array}{l}\text { So-net M3 Company which manages the } \\
\text { biggest website related with health care in } \\
\text { Japan } \\
\text { http://www.m3.com/index.jsp }\end{array}$ & $\begin{array}{l}\text { "M3.com" delivery } \\
\text { service }\end{array}$ \\
\hline
\end{tabular}

Table 1. The cooperation relationship of Yumenomachi

Dot-com companies went through its freeze-up in the beginning of 21 century. After this, the surviving and the new companies became more cautious, avoiding high risks. From 2004, Yumenomachi cooperated with the Index Company and Yahoo parallel. It can be thought that, the strategy was able to avoid risks even if either failed. On February 28, 2007, Index Company terminated the joint business contract and its stocks were taken-over $(19.4 \%)$ bid by Yahoo which became the largest shareholder (41.84\% of the stocks). The collaboration with Yahoo has made Yumenomachi more stable. Based on the platform of Yahoo, the 
business has expanded quickly in recent years. The win-win relation was mutually constructed, and the synergy effect seemed to be significant.

\subsection{The characteristic and architecture of Autonomic Decentralized Enterprise System}

This unique intra-organization network gestated in Yumenomachi may be still an intangible concept. While the goal of the actors involved in this business model is still hard to test in a long-term view. However, according to the basic concept of ADS, the essence ideology of the framework and the configuration of this intra-organizational network could be preconceived. The two main characteristics are autonomous and collaboration.

\subsubsection{The characteristics of ADEM}

(1) Autonomous controllability.

The autonomous controllability is about the flexibility of the human resource management style in the enterprises. As Takaki (1995), Limerick and Cunnington (1993) comment, the new organization of information era is different from the traditional pyramid organization based on the bottom-up vertical relations. The new organization puts emphasis on the horizontal relations among members. In AEDM organization, each member is independent and not affiliated or controlled by any other. Instead of waiting for the instruction from up, along the direction of the whole enterprise, they integrate the necessary business resources to tackle their own situation. Their target is not to satisfy what the up tiers demand or order, but to seek for creative and innovative solution. The motivation of this kind of spontaneous and autonomous activity is the intrinsic motivation called by Deci (1975), which means the motivation is from inside of the performer, brought by curiosity and concern, and the action does not depend on rewards or punishments. The encouragement and satisfaction come from performing an activity rather from a result of the activity.

(2) Autonomous Participation

This feature is about the freedom of the business entity. All business entities have freedom to join or exit the network. No one monitors or controls them in an integrated manner. Therefore, the system can be enlarged or reduced without any influence on the performance of the whole network. In the viewpoint of business innovation, ADEM affords all the participants the platform to establish their own business. The low barrier to enter and the freedom to leave is a driving force that attracts the participants to embrace a variety of E-commerce business. Here in Yumenomachi case, the staffs are encouraged and expected to use the delivery service business platform to build their various delivery service websites.

(3) Autonomous Collaboration

All members connect and collaborate with each other; they share data, information, knowledge, technology and customer resource. In this network, the myriad of powerful computing and communications technologies that facilitate these resources are transparent and easily transplanted.

In the aspects of the individual staffs, if any one adjusts his/her activity according to his/her situation, the others can still coordinate their individual objectives among themselves and it can operate in a coordinated fashion. Considering the business aspect, if any business unit joins or exits from the network, other business units can still operate fluently. Even there is both horizontal and vertical resource integration and connection among them. 


\subsubsection{The architecture of ADEM}

In the study case of this chapter, most of the employees in Yumenomachi have their own clear targets, and their motivation is high. Their enthusiastic devotion to new business could give momentum to the entire company. As mentioned in 4.3.1, the relationship among members in the organization is described in Fig 3 (Right). After the establishment of the institution, all the individuals are expected to take the initiative in solving problems. However, he or she could still obtain assistance from others in the organization.

At present, there are three website services in Yumenomachi. In the future, maybe other start-ups established by other employees will also join this system, such as the aforementioned sports equipment delivery service. They will upgrade the former network while they benefit more from the network if the quantity of members grows up. Then, the new network will attract more members to join in. In the end, it will form the benign circulation. Because the members may be from different business fields, the ADEM model is different from an industrial consortium, and because there is no leader or supervisor, it differs from the branches under a head office.

Figure 3 (left) shows the business architecture of Yumenomachi based on the concept of ADEM. The system with the basic features of equality, locality and self-containment can be realized under this architecture, where there is no central controller or coordinator, all members are not affiliated or controlled by any other. They have their own management system, the Autonomous Management Officer (AMO), to manage themselves and coordinate with others. The self-contained elements, including their respective AMOs, are integrated into system.

In this network, all the business units are connected through the Resource Field (RF); all resources will be broadcasted into the RF and the data itself will be reserved and updated in the RF by integrating the intelligence of all the partners; RF will be established based on the principle of "wikis", as any member can access and update it. Therefore, the RF allows all the participants to create, share and use strategic knowledge to improve operational and strategic efficiency and effectiveness. However, the broadcasting of the resource has one basic rule. As researches argued, the information human being can understand contains two levels (Bateson, 1979). One is the information/message itself, the other is the context of the message. Without the context, it is tough for human beings to understand the information itself. Therefore, instead of the code for sender and receiver, the context should be added during the information being broadcasted. Besides, the members also communicate with each other in the real world. The system management structure may vary depending on the joining or leaving of the subsystems. However, the operation of the each unit will keep as usual. In order to realize a stable implementation of the whole system, the autonomous subsystem has to recognize and evaluate the heterogeneous resources in the RF, to select the appropriate resource and to satisfy its individual requirements by cooperating with other subsystems.

The thinking of ADEM will open up a completely new dimension to E-commerce by enabling individuals to use the convenience of the RF in addition to traditional resources. Also, the ability to share resources across the homogenous business field (delivery service) has made it easier for enterprises to have collaborative planning and design, which removes inefficiencies in the expansion process. 

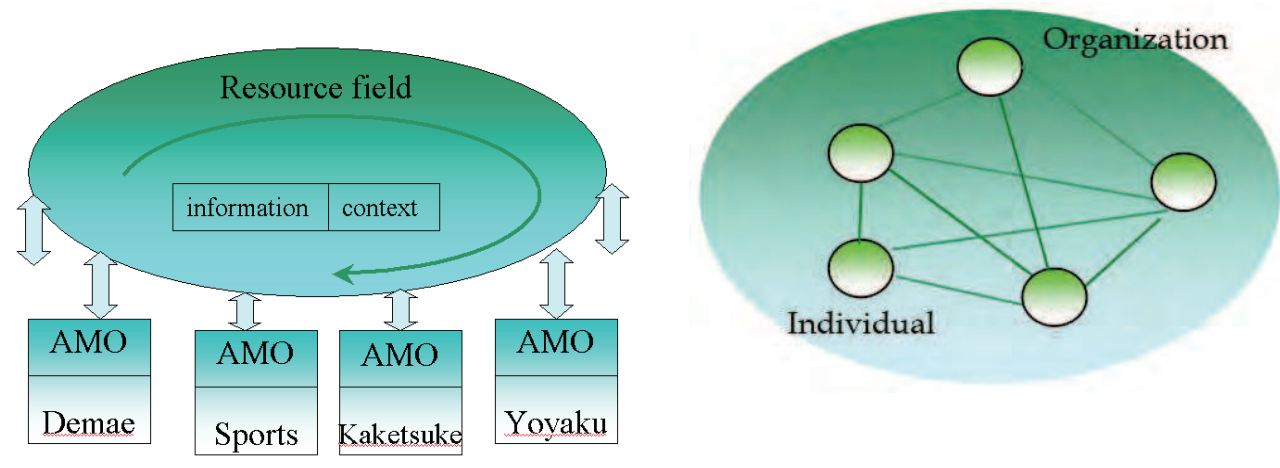

Fig. 3. Architecture of Autonomous Decentralized Enterprises Model

\subsubsection{The two drive-wheels of ADEM organizations}

Seeking for profit is the nature of the enterprises in most cases. If the members cannot realize profit in the system, they will exit and no new one will join in. The system will exist only in name. On the other hand, if the free rider phenomenon becomes very severe, resources will be used out but without updating. However, ensuring the sustainable development of the ADEM organization, the president of Yumenomachi, Ms. Nakamura summarized the two philosophies of business of Yumenomachi, which are also considered as two drive-wheels of ADEM organization. One is the revenue and pure profit, and the other is contribution to the society. They cooperate and interact with each other to boost wealth and promote efficiency in the viewpoint of the whole society. First of all, as private entities, actors in ADEM organizations expect to obtain merit and advantage. It is quiet realistic and essential for the ADEM organizations whether the actors are capable to obtain profit. As Chang, Jackson and Grover illustrated that growth without profitability is not sustainable. Many e-commerce companies had high valuations based on an excessive focus on high growth shown by their attracting new customers. However, their inability to generate profit proved detrimental. Therefore, Gross Profit Margin (GPM) is the real measure of an organization's performance efficiency. The contribution to the society, as the joint vision of ADEM organizations is the other wheel. It could be considered to be the stimulant of spiritual dimension for all actors as a long-term vision of the organization. The social joint-vision will work as a catalyst for knowledge sharing, innovation and cooperation inside the organization. Meanwhile, the social contribution oriented mission of the organization will facilitate attainment of empathy and cooperation from outside. As a consequence, the harmonic inside and outside environment will be favorable to realize the profit for all the actors in the organization.

\section{Conclusion}

The rapid popularization of Web 2.0 coupled with the growth of e-commerce gives rise to enormous opportunities as well as changes for the creation of new intra-organization models. In the evolving environment of the E-business, this study has attempted to contribute to the framework description of a new type of inter-organizational model in e-commerce enterprises: Autonomous Decentralized Enterprise Model. From this case study, 
one conclusion is that the emergence of autonomous decentralized model is not accidental, but generated from the dual effects of the external environment and the internal catalyst factor. Moreover, the foundational features and configuration blueprint of the ADEM according to the rudiment organization of Yumenomachi is also described in this chapter.

For these years, the greatest impact of Web2.0 has been its ability to create linkage outside the enterprises and platforms inside the enterprise. The ADEM might not have existed just a few short years ago because there was no widely accepted platform for continuous and unattended share and exchange of information and knowledge about markets, customers, demand, inventories and so forth. Today, such autonomous and collaborative networks could be evolving in every economic field, as they support the business-to-consumer commerce, business-to-business commerce, government-to-citizen interactivity, peer-to-peer exchanges, and internal connectivity. Such organization based on the ADEM will allow enterprises to be dynamic and flexible, thereby allowing rapid changes in their strategies and activities. Meanwhile, the participants can use the platform afforded by the organization to create new business opportunity easily, leading to further improvements in collaboration and sustainable development of the organization. One predication is that ADEM could generate positive performance and its application could be promising in the Web 2.0 era, even the emerging Web 3.0 era recently. However, the free rider is always inevitable phenomenon. Only the emphasis on the social contribution and self-conscious might not be effective enough to avoid the failure caused by free rider. Therefore, the reasonable principles or standards to define the responsibility are necessary. This will be key point for the future study.

\section{Acknowledgment}

The authors would like to thank for all the interviewees in Yumenomachi, especially thank Ms. Nakamura, she was generous with her time and knowledge. Thanks are also due to Prof.Osam Tomisawa, in Kochi University of Technology, Prof. Guangchen, in Southwest Jiaotong University, for their precious suggestions for this research. This work was partly finished when the first author studied in Kochi University of Technology.

\section{References}

Bateson, Gregory (1979). Mind and Nature, John Brockmab Association.

Deci, Edward L.(1975), Intrinsic Motivation, Plenum Press.

Geoffrion, A.,R. Krishnan. 2001. Prospects for operations research in the e-business era. Interfaces 31 (2) 6-36.

H,Takaki. Network Leadership JUSE Press, 1995, pp: 73-87

Jayashankar M. Swaminathan - Sridhar R. Tayur Models for Supply Chains in E-Business Management Science/Vol. 49, No. 10, October 2003 pp. 1387-1406

J.D. Thompson, Organizations in Action, McGraw-Hill, NY, 1967.

K.-c. Chang et al. E-commerce and corporate strategy: an executive perspective Information \& Management 2023 (2002) 1-13

Limerick, Cunnington. Managing the New Organization, Jossey-Bass, 1993

Mori, K. et al., "Proposition of Autonomous Decentralized Concept", Trans. IEE of Japan, vol.104C, no. 12, pp.303-340, 1984 
Raphael Amit, Christoph Zott, Value creation in E-business Strategic Management Journal Strat. Mgmt. J., 22: 493-520 (2001)

Seung Chang Lee, Bo Young Pak, Ho Geun Lee.B usiness value of B2B electronic commerce: the critical role of inter-firm collaboration Electronic Commerce Research and Applications 2 (2003) 350-361

Tapscott, Don and Anthony D. Williams. 2007. Wikinomics: How Mass Collaboration Changes Everything. New York: Penguin.

V. Zwass, Electronic commerce: Structures and issues, Journal of Electronic Commerce 1 (1), 1996, pp. 3-23.

V. Zwass, Structure and macro-level impacts of electronic commerce: from technological infrastructure to electronic marketplaces, In: K.E. Kendall (Ed.), Emerging Information Technologies, Sage, Thousand Oaks, CA, 1998, http:// www.mhhe.com/business/mis/zwass/ecpaper.html.

Y.J. Bakos, Reducing buyer search costs: implications for electronic marketplaces, Management Science 43 (12), 1997, pp. 1676-1708.

http://www.yumenomachi.co.jp/

http://demae-can.com/

http://kaketsuke-can.com/

http://yoyaku-can.com/

http://delivery.gourmet.yahoo.co.jp/

http://demae.hotpepper.jp/

http:/ / www.so-netm3.co.jp/

http://www.hot-station.co.jp/

http://www.index-hd.com/

http://www.jbr.co.jp/.

http://www.mediaflag.co.jp/

http:/ / en.wikipedia.org/wiki/Web2.0

http://www.sdl.hitachi.co.jp/english/glossary/a/adss.html 


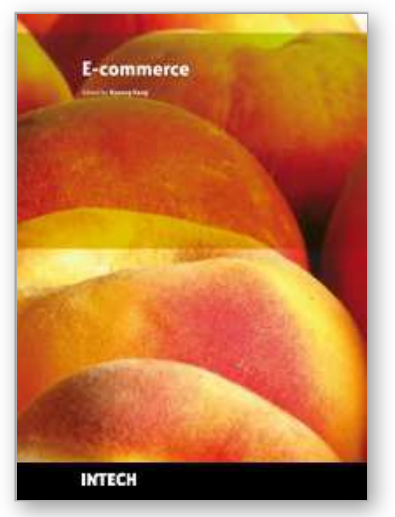

\author{
E-commerce \\ Edited by Kyeong Kang
}

ISBN 978-953-7619-98-5

Hard cover, 284 pages

Publisher InTech

Published online 01, February, 2010

Published in print edition February, 2010

E-commerce provides immense capability for connectivity through buying and selling activities all over the world. During the last two decades new concepts of business have evolved due to popularity of the Internet, providing new business opportunities for commercial organisations and they are being further influenced by user activities of newer applications of the Internet. Business transactions are made possible through a combination of secure data processing, networking technologies and interactivity functions. Business models are also subjected to continuous external forces of technological evolution, innovative solutions derived through competition, creation of legal boundaries through legislation and social change. The main purpose of this book is to provide the reader with a familiarity of the web based e-commerce environment and position them to deal confidently with a competitive global business environment. The book contains a numbers of case studies providing the reader with different perspectives in interface design, technology usage, quality measurement and performance aspects of developing web-based e-commerce.

\title{
How to reference
}

In order to correctly reference this scholarly work, feel free to copy and paste the following:

Feng Liu and Makoto Hirano (2010). Autonomous Decentralized Enterprise Model - A New Wave in Web 2.0 Type E-commerce, E-commerce, Kyeong Kang (Ed.), ISBN: 978-953-7619-98-5, InTech, Available from: http://www.intechopen.com/books/e-commerce/autonomous-decentralized-enterprise-model-a-new-wave-inweb-2-0-type-e-commerce

\section{INTECH}

open science | open minds

\section{InTech Europe}

University Campus STeP Ri

Slavka Krautzeka 83/A

51000 Rijeka, Croatia

Phone: +385 (51) 770447

Fax: +385 (51) 686166

www.intechopen.com

\section{InTech China}

Unit 405, Office Block, Hotel Equatorial Shanghai

No.65, Yan An Road (West), Shanghai, 200040, China

中国上海市延安西路65号上海国际贵都大饭店办公楼405单元

Phone: +86-21-62489820

Fax: $+86-21-62489821$ 
(C) 2010 The Author(s). Licensee IntechOpen. This chapter is distributed under the terms of the Creative Commons Attribution-NonCommercialShareAlike-3.0 License, which permits use, distribution and reproduction for non-commercial purposes, provided the original is properly cited and derivative works building on this content are distributed under the same license. 